Airways; Busk prize, to W. J. G. Pinsker, Royal Aircraft Establishment; Hodgson prize, to S. D. Davies, Dowty Rotol Ltd; Ackroyd Stuart prize, to J. L. Edwards, Rolls-Royce (1971) Ltd; Pilcher-Usborne prize, to D. L. Birdsall, University of Bristol; Alan Marsh award, to D. A. S. Howell, Westland Helicopters Limited.

Erratum. In the article "Induction of Cellular DNA Synthesis in Human Leucocytes by Epstein-Barr Virus" by P. Gerber and B. H. Hoyer (Nature, 231, $46 ; 1971)$, the first sentence of the third paragraph should read "We have shown previously ${ }^{9}$ that leucocytes from adult human donors who had no previous EBV infection had a limited life-span in vitro and could not be established in long term culture".

\section{International Meetings}

June 7-9, Cellular Antigens, Philadelphia (Dr A. Nowotny, Temple University School of Medicine, 3400 North Broad Street, Philadelphia, Pennsylvania 19140, USA).

July 5-8, Acetylenes, Allenes and Cumulenes, Nottingham (Dr J. F. Gibson, The Chemical Society, Burlington House, London W1V 0BN).

September 1-3, Multivariable Control System Design and Applications, Manchester (Institution of Electrical Engineers, Savoy Place, London WC2R 0BL).

September 20-October 16, Policies for Science and Technology in Relation to Economic Development; Brighton (The Administrator, Seminary 23, Institute of Development Studies, Andrew Cohen Building, University of Sussex, Falmer, Brighton BL1 9RE, Sussex).

September 21-24, Quantum Theory, York (Secretary, Department of Mathematics, University of York, Heslington, York YO1 5DD).

September 21-24, Theory of Atomic and Molecular Spectroscopy, York (The Secretary, Department of Mathematics, University of York, Heslington, York YO1 5DD).

September 22-23, High Voltage Electron Microscopy, Teddington (Mėetings Officer, Institute of Physics, 47 Belgrave Square, London SW1).

September 26-29, Study of Lysozymes, Herceg Novi (Professor V. Pantic, Division of Cytology and Embryology, Institute for Biological Research, 29-Novembar 142, 11000 Belgrade, Yugoslavia).

September 27-29, Teaching Mathematics to Non-specialists, Loughborough (Secretary and Registrar, Institute of Mathematics and its Applications, Maitland House, Warrior Square, Southend-onSea, Essex SS1 2JY).
September 27-October 2, Pneumoconiosis, Bucharest (Pneumoconiosis Conference Committee, Ministerul Muncii, Str. Scaune nr 1-3, Bucharest, Romania).

September 28-October 1, Recent Chemistry and Biochemistry of Phenolic Compounds, Dublin (Dr J. B. Harborne, Botany Department, The University, Reading RG1 5AQ).

September 28-29, Protein and RNA Factors in Initiation of Protein Synthesis in Mammalian Cells, Coventry (Dr D. W. Hutchinson, School of Molecular Sciences, University of Warwick, Coventry CV4 7AL).

October 1-5, Basic Environment Problems of Man in Space, Yerevan, USSR (Secretary, International Academy of Astronautics, 250 Rue Saint-Jacques, 75 Paris 5 , France).

October 11-13, Excitation Sources, London (Meetings Officer, The Institute of Physics and the Physical Society, 47 Belgrave Square, London SW1).

October 12 -16, Communication and Transport, Genoa (Istituto Internazionale delle Comunicazioni, 18 Viale Brigate Partigiane, 16129 Genova, Italy).

October 21-22, Polymers in Cosmetic Formulations, Paris (Mr Y. Tollard, d'Audiffret, Laboratoire de Recherches Unilever, 8, Impasse de la Montjoie, 93-La Plaine-St Denis, France).

October 25-28, International Research and Development Exhibition and Conference, London (G. A. Pugsley, R. W. Boardman Exhibitions Limited, 8 Leicester Square, London WC2H 7BN).

October 27-30, Society for Neuroscience Meeting, Washington DC (Neuroscience Meeting Headquarters, 1629 K Street NW, Suite 700, Washington DC 20006, USA).

November 5-7, Genesis of Base Metal Deposits in Ireland, Galway (Professor D. Skevington, Geology Department, University College, Galway, Ireland).

November 7-11, Communication for Decision-Makers, Denver (Mīiss S. Wormley, American Society for Information Science, 1140 Connecticut Avenue NW, Suite 804, Washington DC 20036, USA).

November 11, Acoustic Surface Waves and their Applications, London (Meetings Officer, Institute of Physics, 47 Belgrave Square, London SW1).

November 16, Selectivity in Organic Synthesis, London (Dr M. J. Soulal, Beecham Research Laboratories, Brockham Park, Betchworth, Surrey).

November 17-19, Rationalization of the Processing Chain, Brussels (Dr P. A. Arias-Soto, Secretary, EVAF Textile Division, 22 Square Robert Goldschmidt, 1050 Brussels, Belgium).
November 29-December 3, Biotelemetry, Pretoria (Symposium Secretariat, Information and Research Services, CSIR, PO Box 395, Pretoria, South Africa).

November 29-30, Discharge of Industrial Effluents to Municipal Sewerage Systems, London (Mr V. H. Lewin, Institute of Water Pollution Control, Heyford Hill Cottage, Littlemore, Oxford).

December 6-11, Exposition de Physique France (Société Francaise de Physique, 33 rue Croulebarbe, Paris 13).

February 9-15, 1972, Oceanography of the South Pacific, Wellington (The Secretary, National Commission for Unesco, Department of Education, Private Bag, Wellington, New Zealand).

\section{British Diary}

\section{Monday, May 24}

Power Switching by Vacuum Contactors and Thyristors (5.30 p.m. discussion) Institution of Electrical Engineers, at Savoy Place, London WC2.

The Teaching of Electrical Circuit Theory (5.30 p.m. discussion) Institution of Electrical Engineers, at Savoy Place, London WC2.

\section{Tuesday, May 25}

Digital Control of an Integrated Forging Press (5.30 p.m.) Mr J. P. Russell, Institution of Electrical Engineers, at Savoy Place, London WC2.

Human Conception (5.15 p.m.) Dr R. G. Edwards, Institution of Biology, with the support of the Eugenics Society, in the Lecture Hall, Natural History Museum, Cromwell Road, London SW7. (Eleventh Darwin Lecture in Human Biology.)

Printed Resistors and their Use in Precision de Potentiometers (5.30 p.m.) Mr V. S. Umantsev, Institution of Electrical Engineers, at Savoy Place, London WC2.

RF Measurements on Solid-state Active Devices (9.30 a.m. colloquium) Institution of Electrical Engineers, jointly with the Institution of Electronic and Radio Engineers, at Savoy Place, London WC2.

\section{Wednesday, May 26}

Electricity in Horticulture (5.30 p.m.) Mr. F. M. Proctor and Mr J. A. C. Weir, Institution of Electrical Engineers, at Savoy Place, London WC2.

Problems of Classification of Haemophilus Species (2 p.m.) Professor K. Zimmermann, University of London, at the Royal Postgraduate Medical School, Hammersmith Hospital, Du Cane Road, London W12. 